\title{
HUBUNGAN ANTARA INISIASI MENYUSU DINI DENGAN PEMBERIAN ASI EKSLUSIF DI DESA SINGASARI KECAMATAN SINGAPARNA KABUPATEN TASIKMALAYA TAHUN 2018
}

\author{
Erwina Sumartini, S.ST., M.Keb \\ erwinasumartini5@gmail.com
}

Nurul Herawati

Sekolah Tinggi Ilmu Kesehatan (STIKes) Respati

\begin{abstract}
A. ABSTRAK
Menurut data Riskesdas 2013, persentase nasional proses mulai menyusu kurang dari satu jam (IMD) setelah bayi lahir adalah 34,5\%. Persentase di Jawa Barat untuk proses mulai menyusu kurang dari satu jam (IMD) setelah bayi lahir adalah 29,0 \%; masih jauh dari angka persentase nasional. Persentase IMD di Kecamatan Singaparna adalah 28,5\% (Dinkes Tasikmalaya, 2017); juga masih jauh dari angka persentase nasional, sehingga menyebabkan penulis untuk melakukan penelitian mengenai hubungan IMD dengan pemberian ASI eksklusif di Singaparna.

Jenis penelitian ini adalah observasional analitik pendekatan kasus kontrol study, melalui angket dan pengukuran. Metode pengambilan sampel dalam penelitian ini dilakukan dengan menggunakan teknik non probability sampling yaitu pengambilan sampel bukan secara acak. Metode yang digunakan dalam penelitian ini adalah total sampling yaitu sebanyak 50 responden dengan populasi semua ibu menyusui di Desa Singasari di Kecamatan. Alat ukur yang digunakana pada penelitian ini yaitu wawancara terpimpin, angket dan pengukuran. Pada penelitian ini penliti mengguankan 2 analisa data yaitu, univariat dan bivariate. dapat diketahui bahwa ada hubungan antara inisiasi menyusu dini dengan asi ekslusif $(\mathrm{p}<0,05)$.
\end{abstract}

Kata kunci : IMD, asi ekslusif, bayi baru lahir 


\section{B. PENDAHULUAN}

Pemberian ASI secara optimal sangat penting. Jika semua anak usia 0-23 bulan mendapat ASI optimal, maka selama periode ini dapat mendorong perkembangan anak, mengurangi resiko penyakit kronis, dan menurunkan morbiditas dan mortalitas. Target SDGs diakhir tahun 2030 pada tujuan ketiga yakni mengurangi angka kematian neonatal 12 per 1000 kelahiran dan angka kematian anak dibawah 5 tahun 25 per 1000 kelahiran (WHO, 2016; WHO, 2017). Menurut data Riskesdas 2013, persentase nasional proses mulai menyusu kurang dari satu jam (IMD) setelah bayi lahir adalah 34,5 $\%$.

Persentase di Sulawesi Utara untuk proses mulai menyusu kurang dari satu jam (IMD) setelah bayi lahir adalah 29,0 \%; masih jauh dari angka persentase nasional. Persentase IMD di Kota Manado adalah 28,5\% (Dinkes Sulut, 2017); juga masih jauh dari angka persentase nasional, sehingga menyebabkan penulis untuk melakukan penelitian mengenai hubungan IMD dengan pemberian ASI eksklusif di Singaparna. Rendahnya pemberian ASI merupakan ancaman bagi tumbuh kembang anak. Bayi yang tidak diberi ASI secara eksklusif dapat berakibat buruk pada gizi dan kesehatan bayi (Zaenab, 2016). Bayi mengalami defisiensi gizi khususnya vitamin $A$, vitamin $D$, kalsium, yodium, zat besi, dan asam folat. Kekurangan vitamin A dan zat besi dapat meningkatkan resiko morbiditas dan mortalitas bayi serta gangguan perkembangan kognitif. Sedangkan defisiensi asam folat meningkatkan resiko cacat pada syaraf (Kureishy et al, 2017). Kandungan antibodi dalam ASI mampu menginduksi sistem imun tubuh sehingga anak yang diberi ASI eksklusif tidak mudah sakit dan mengurangi morbiditas infeksi sistem pencernaan dan diare (Hartinah dan Dewi, 2016). Anak yang diberikan ASI eksklusif memiliki resiko lebih rendah terkena infeksi gastrointestinal dibanding anak yang hanya mendapat ASI selama 3-4 bulan. Di Indonesia, penyakit diare menjadi penyebab utama kematian anak dengan persentase $31,4 \%$ (Tamimi, Jurnalis \& Sulastri, 2016). Selain itu, anak yang mendapatkan ASI eksklusif juga tidak mudah terkena Infeksi Saluran Pernapasan Atas (ISPA). Survei mortalitas yang dilakukan Subdit ISPA menempatkan pnemonia sebagai salah satu penyebab kematian balita dengan persentase 23,6\% (Rahman dan Nur, 2015). IMD atau kemampuan untuk melakukan penyusuan segera (immediate breastfeeding) merupakan salah satu faktor keberhasilan ASI eksklusif. Bila ibu difasilitasi oleh penolong persalinan untuk IMD diharapkan interaksi ibu dan bayi ini akan segera terjadi. Dengan IMD, ibu semakin percaya diri untuk tetap memberikan ASI-nya dan bayi bisa nyaman menempel pada payudara ibu atau tenang dalam pelukan ibu segera setelah lahir (Fikawati dan Syafiq, 2009). Menurut hasil penelitian Agudelo et al (2016) kontak kulit dengan kulit bermanfaat bagi ibu dan janin. Kontak kulit dengan kulit berhubungan dengan durasi menyusui secara eksklusif pada bayi. Faktor - faktor yang mempengaruhi keberhasilan IMD yaitu keadaan bayi yang bugar, keadaan ibu yang baik, keluarnya kolostrum dan peran petugas kesehatan. Bayi bugar adalah bayi yang lahir langsung menangis, warna kulit kemerahan, tonus otot baik. Bayi harus berada dalam keadaan yang sehat ketika melakukan kontak kulit dengan ibu. Kedua, keluarnya kolostrum membantu bayi mendapatkan puting susu ibu karena bau yang dihasilkan 
kolostrum sama dengan bau yang ada pada telapak tangan bayi. Ketiga, petugas kesehatan harus memiliki kesabaran untuk menunggu bayi dalam usahanya mencapai puting susu (Susanti dan Armi, 2014). Berdasarkan latar belakang diatas peneliti

\section{METODE PENELITIAN}

Jenis penelitian ini adalah observasional analitik pendekatan kasus kontrol study, melalui angket dan pengukuran. Metode pengambilan sampel dalam penelitian ini dilakukan dengan menggunakan teknik non probability tertarik untuk mengetahui hubungan antara iniasi menyusu dini (IMD) dengan dengan pemberian ASI ekslusif di Desa Singasari Kecamatan Singaparna Kabupaten Tasikmalaya.

sampling yaitu pengambilan sampel bukan secara acak. Metode yang digunakan dalam penelitian ini adalah total sampling yaitu sebanyak 50 responden dengan populasi semua ibu menyusui di Desa Singasari di Kecamatan. Alat ukur yang digunakana pada penelitian ini yaitu wawancara terpimpin, angket dan pengukuran. Pada penelitian ini penliti mengguankan 2 analisa data yaitu, univariat dan bivariate

\section{HASIL PENELITIAN}

\section{Analisis Univariat Karakteristik Responden}

Berdasarkan hasil penelitian dapat diketahui gambaran karakteristik responden penelitian di Kecamatan Singaparna sebagai berikut :

A. Distribusi Responden Berdasarkan Pekerjaan

Berdasarkan hasil wawancara yang dilakukan, maka distribusi responden berdasarkan pekerjaan dapat diketahui pada Tabel 4.1

Tabel 4.1 Distribusi Karakteristik Responden berdasarkan pekerjaan

\begin{tabular}{|r|l|c|c|}
\hline \multirow{2}{*}{ No } & \multirow{2}{*}{ Jenis Kelamin Balita } & \multicolumn{2}{|c|}{ Responden } \\
\cline { 3 - 4 } & & Jumlah & Persentase \\
\hline 1. & IRT & 20 & 40,0 \\
\hline 2. & Pedagang & 30 & 60,0 \\
\hline & Jumlah & 50 & 100,0 \\
\hline
\end{tabular}

Tabel 4.1 menunjukkan bahwa responden pedagang memiliki proporsi paling banyak $(60,00 \%)$ dibandingkan responden IRT $(40,0 \%)$.

B. Distribusi Responden Berdasarkan umur

Berdasarkan hasil wawancara yang dilakukan, maka distribusi responden berdasarkan umur dapat diketahui pada Tabel 4.2

Tabel 4.2 Distribusi Karakteristik Responden berdasarkan umur

\begin{tabular}{|l|l|c|c|}
\hline \multirow{2}{*}{ No } & \multirow{2}{*}{ Umur } & \multicolumn{2}{|c|}{ Responden } \\
\cline { 3 - 4 } & & Jumlah & Persentase \\
\hline 1. & $16-20$ & 10 & 20,0 \\
\hline 2. & $21-25$ & 10 & 20,0 \\
\hline 3. & $26-30$ & 30 & 60,0 \\
\hline & Jumlah & 50 & 100,0 \\
\hline
\end{tabular}


Tabel 4.2 menunjukkan bahwa responden yang berumur 26-30 tahun memiliki proporsi tertinggi (60,0\%), sedangkan responden yang berumur 16-20 dan 21-25 tahun memiliki proporsi terendah $(20,0 \%)$.

b. Distribusi Responden Berdasarkan Pendidikan

Berdasarkan hasil wawancara yang dilakukan, maka distribusi responden berdasarkan umur dapat diketahui pada Tabel 4.3

Tabel 4.3 Distribusi Karakteristik Responden berdasarkan pendidika

\begin{tabular}{|l|l|c|c|}
\hline \multirow{2}{*}{ No } & \multirow{2}{*}{ Umur } & \multicolumn{2}{|c|}{ Responden } \\
\cline { 3 - 4 } & & Jumlah & Persentase \\
\hline 1. & SD & 20 & 60,0 \\
\hline 2. & SMP & 10 & 20,0 \\
\hline 3. & SMA & 10 & 20,0 \\
\hline & Jumlah & 50 & 100,0 \\
\hline
\end{tabular}

Tabel 4.3 menunjukkan bahwa responden yang berumur SD memiliki proporsi tertinggi $(60,0)$, sedangkan responden yang berpendidikan SMP dan SMA memiliki proporsi terendah $(20,0)$.

2. Analisis Bivariat

Tabel 4.4 Hasil Analisis Bivariat Hubungan Variabel Bebas dengan Faktor risiko status gizi ibu hamil.

\begin{tabular}{|c|c|c|c|c|c|c|c|c|}
\hline \multirow[t]{3}{*}{ No } & \multirow[t]{3}{*}{ Variabel } & \multicolumn{4}{|c|}{ ASI EKSLUSIF } & \multirow[t]{3}{*}{ OR } & \multirow[t]{3}{*}{$95 \% \mathrm{C1}$} & \multirow[t]{3}{*}{ P-value } \\
\hline & & $\mathbf{Y A}$ & & 1 & DAK & & & \\
\hline & & $\mathbf{n}$ & $\%$ & $\mathbf{n}$ & $\%$ & & & \\
\hline 1 & $\begin{array}{l}\text { IMD } \\
\text { Tidak } \\
\text { Ya }\end{array}$ & $\begin{array}{r}20 \\
5\end{array}$ & $\begin{array}{l}80,0 \\
20,0\end{array}$ & $\begin{array}{r}5 \\
20\end{array}$ & $\begin{array}{c}20,0 \\
80,0\end{array}$ & 10,0 & $3,56-61,55$ & $0,000 *$ \\
\hline
\end{tabular}

\section{E. PEMBAHASAN}

Berdasarkan Tabel 4.4 dapat diketahui bahwa ada hubungan antara inisiasi menyusu dini dengan asi ekslusif ( $p<0,05)$. Odds Ratio adalah 10 sehingga diinterpretasikan orang yang tidak IMD berisiko 10 kali lipat tidak berhasil dalam Asi Ekslusif. Hasil penelitian ini sejalan dengan penelitian Priscilla dan Elmatris (2011) di Kota Solok dan penelitian Maastrup et al (2013) di Denmark. Inisiasi Menyusui Dini (IMD) merupakan awal keberhasilan pemberian ASI Eksklusif. dengan latar belakang melahirkan anak pertama dan belum memiliki pengalaman
Inisiasi Menyusui Dini (IMD) dapat memantapkan ibu untuk memberikan ASI kepada bayi sampai 6 bulan. Memberikan ASI sejak awal kelahiran memberi kesempatan bayi untuktu tidak dilakukan rawat gabung (rooming-in), penggunaan alat kontrasepsi kombinasi, stress, dan pengalaman menyusui. Terdapat 10 responden yang memberikan susu formula sebelum bayi berusia 6 bulan

menyusui. Sesuai dengan teori Fitriyani dan Aisyah (2016) Ibu yang melahirkan lebih dari 
satu kali produksi ASI-nya jauh lebih tinggi dibandingkan ibu yang melahirkan pertama kali. Jumlah persalinan yang pernah dialami ibu juga memberikan pengalaman dalam memberikan ASI kepada bayi. Hal tersebut sejalan dengan hasil penelitian Agow, Umboh dan Lestari (2017) bahwa ada hubungan antara paritas ibu dengan pemberian ASI eksklusif di Wilayah Kerja Puskesmas Motoboi Kecil Kota Kotamobagu. Paritas dikaitkan dengan arah pencarian informasi tentang pengetahuan ibu nifas/menyusui dalam memberikan ASI eksklusif. Inisiasi Menyusu Dini adalah

\section{F. KESIMPULAN DAN SARAN}

Ada hubungan antara IMD dengan Asi Ekslusif di Desa Singasari Kecamatan Singaparana. Saran bagi petugas kesehatan untuk lebih mensosialisasikan ASI Ekslusif bagi masyarakat

\section{G. REFERENSI}

Adam, A. Alim, A. Sari, N. (2016). Pemberian Inisiasi Menyusu Dini Pada Bayi Baru Lahir. Jurnal Kesehatan Manarang Volume 2 Nomor 2, Desember 2016 http://ejournal.poltekkesmamuju.ac.id/index.php /jkm/article/view/31/0, diakses 15 Desember 2017.

Agudelo, S. Gamboa, O. Rodriguez, F. Cala, S. Gualdron, N. Obando, E and Padron, M.L. (2016). The effect of skinto-skin contact at birth, early versus immediate, on the duration of exclusive human lactancy in full-term newborns treated at the Clinica Universidad de La Sabana: study protocol for a randomized clinical trial. Biomed Central (2016) $17: 251$ memberikan kesempatan bayi memulai atau inisiasi menyusu sendiri segera setelah lahir atau dini dengan membiarkan kontak kulit bayi dengan kulit ibu setidaknya satu jam atau lebih sampai menyusu pertama selesai. Apabila dalam satu jam tidak ada reaksi menyusu, maka boleh mendekatkan puting susu tetapi beri kesempatan bayi untuk inisiasi. Dalam prosedur ini kontak kulit bayi dengan kulit ibu (skin to skin) lebih bermakna dibandingkan dengan proses inisiasi itu sendiri (Saputra dan Lasmini, 2015).

https://www.ncbi.nlm.nih.gov/pubmed/27 782829, diakses 10 Desember 2017.

Fikawati dan Syafiq. (2009). Penyebab Keberhasilan dan Kegagalan Praktik Pemberian ASI Eksklusif. Jurnal Ilmu Kesehatan Masyarakat Nasional Vol. 4 No.

http://jurnalkesmas.ui.ac.id/kesmas/articl e/view/184/184, diakses 5 Desember 2017. Gultie, T dan Sebsibie, G. (2016).

Determinants of suboptimal breastfeeding practice in Debre Berhan town, Ethiopia: a cross sectional study. International Breastfeeding Journal (2016) 11:5 https://www.ncbi.nlm.nih.gov/pmc/article s/PMC4802615, diakes 1 Januari 2018.

Handayani, S dan Husna, P.H. (2016). Faktor Determinan Rendahnya Pemberian ASI Eksklusif. Jurnal Keperawatan $\begin{array}{llll}\text { Volume } & 5 & \text { Nomor } & 1 .\end{array}$ http://journal.akpergshwng.ac.id/index.ph p/gsh/article/view/19, diakses 11 November 2017. Hariani, R. Amareta, D.I. dan Suryana, A.L. (2016). 
Pola Pemberian ASI dan Makanan Pendamping ASI Terhadap Grafik Pertumbuhan Pada Kartu Menuju Sehat (KMS). Jurnal Ilmiah Inovasi 16 Nomor 1.
11

https://publikasi.polije.ac.id/index.php/jii/ article/view/5, diakses 11 November 2017. 